\title{
Closed Die Hammer Forging of Inconel 718
}

\author{
S. Chenna Krishna, ${ }^{1}$ Satish Kumar Singh, ${ }^{1}$ S. V. S. Narayana Murty, ${ }^{1}$ \\ Ganji Venkata Narayana, ${ }^{2}$ Abhay K. Jha, ${ }^{1}$ Bhanu Pant, ${ }^{1}$ and Koshy M. George ${ }^{1}$ \\ ${ }^{1}$ Materials and Mechanical Entity, Vikram Sarabhai Space Centre, Trivandrum 695 022, India \\ ${ }^{2}$ Human Spaceflight Project, Vikram Sarabhai Space Centre, Trivandrum 695 022, India \\ Correspondence should be addressed to S. Chenna Krishna; chenna.sk@gmail.com
}

Received 26 July 2014; Revised 6 November 2014; Accepted 10 November 2014; Published 1 December 2014

Academic Editor: Elena V. Pereloma

Copyright (C) 2014 S. Chenna Krishna et al. This is an open access article distributed under the Creative Commons Attribution License, which permits unrestricted use, distribution, and reproduction in any medium, provided the original work is properly cited.

\begin{abstract}
A method for the production of Inconel 718 (IN-718) hemispherical domes by closed die hammer forging is proposed. Different combination of operations employed for production are as follows: (i) preforging + final forging + air cooling, (ii) preforging + final forging + controlled cooling, (iii) direct forging + controlled cooling, and (iv) direct forging + air cooling. Last three combinations yielded a crack free hemispherical dome. The forged hemispherical domes were solution annealed at $980^{\circ} \mathrm{C}$ for $1 \mathrm{~h}$ and air cooled. The grain size of the domes at all locations was finer than ASTM No 4. Mechanical properties of the forged dome in solution treated and aged condition (STA) were better than feedstock used.
\end{abstract}

\section{Introduction}

Inconel 718 (IN-718) is a widely used age-hardenable nickel based superalloy for high temperature applications. In addition, it is also being used for fabrication of gas bottles for storage of high pressure oxygen for space missions. The rationale for selecting IN-718 for oxygen storage is discussed in literature $[1,2]$. Realization of gas bottles for oxygen storage involves joining two hemispherical domes by welding. Hemispherical domes can be produced by closed die hammer forging or press forging. In the present study, closed die hammer forging was employed due to nonavailability of large press. Even though published work is available on development of large forgings, it is mostly confined to processing using press [3-5]. There are no reports on production of IN-718 hemispherical domes by closed die hammer forging or press forging in open literature. Nevertheless, the forging temperature for IN-718 processed by different technique is well documented in the literature [6-9]. To a larger extent, IN-718 is being hot worked in the temperature range of $980-$ $1120^{\circ} \mathrm{C}[8,9]$. In the present study a forging temperature of $1050^{\circ} \mathrm{C}$, which is above solvus of delta phase, was chosen. Through this work, effort has been made to produce IN-718 hemispherical domes by closed die hammer forging.

\section{Material and Method}

The material used in the present work was $\varnothing 200 \mathrm{~mm} \times$ $40 \mathrm{~mm}$ (height) disc of Inconel 718 produced by VIM + VAR process. The chemical composition of the alloy in wt.\% is $53.1 \mathrm{Ni}-18 \mathrm{Cr}-5.15(\mathrm{Nb}+\mathrm{Ta})-3.02 \mathrm{Mo}-0.5 \mathrm{Al}-0.92 \mathrm{Ti}-0.08 \mathrm{Co}-$ $0.05 \mathrm{C}-0.2 \mathrm{Mn}-0.004 \mathrm{~B}-0.04 \mathrm{Cu}-\mathrm{Bal}(\mathrm{Fe})$. Different operations employed in deformation processing of hemispherical domes include preforging, final forging, controlled cooling, and air cooling. Both of the forging operations were performed by soaking the job at $1050^{\circ} \mathrm{C}$ and finish temperature was maintained above $980^{\circ} \mathrm{C}$. Finish forging temperature was monitored using an optical pyrometer. Preforging was an upsetting operation involving a reduction in the height of the disc from 40 to $23 \mathrm{~mm}$ between flat dies using a $6 \mathrm{~T}$ hammer. Final forging involved realization of a hemispherical dome of $15 \mathrm{~mm}$ thickness by closed die hammer forging using a $10 \mathrm{~T}$ hammer. The process parameters, lubricants, and equipment used for preforging and final forging are given in Table 1. Prior to forging, the work piece was heated in an electric furnace with an accuracy of $\pm 5^{\circ} \mathrm{C}$. The dies for forging were heated to $350^{\circ} \mathrm{C}$ using a gas-fired flame. Different types of combinations employed in the study are given in Figure 1. Controlled cooling involved loading of the forged dome into 


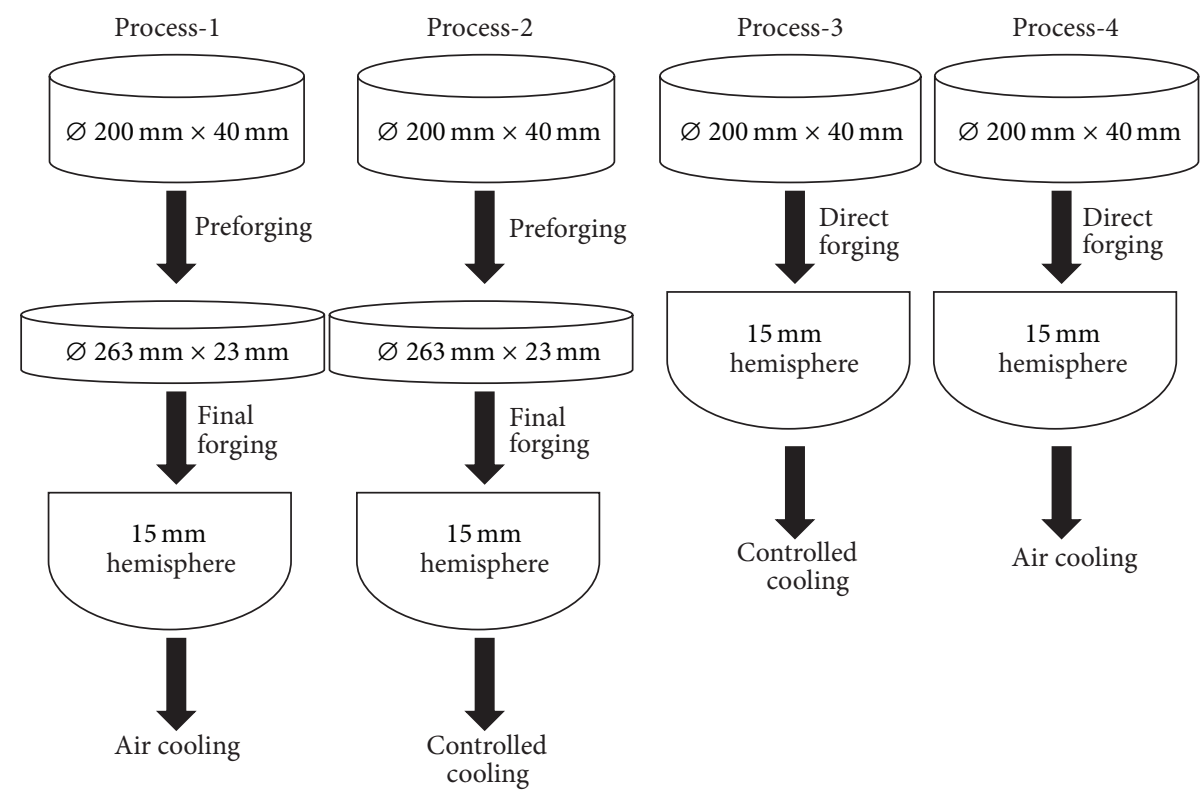

FIGURE 1: Different processing sequence employed in the study.

TABLE 1: Process parameters and equipment used for forging.

\begin{tabular}{lcc}
\hline Detail & Preforging & Final forging \\
\hline Equipment & 6-ton hammer & 10-ton hammer \\
Billet material & Inconel 718 & Inconel 718 \\
Billet dimension & $\varnothing 200 \mathrm{~mm} \times 40 \mathrm{~mm}$ & $\emptyset 263 \mathrm{~mm} \times 23 \mathrm{~mm}$ \\
$\varnothing 200 \mathrm{~mm} \times 40 \mathrm{~mm}$ \\
$\begin{array}{l}\text { Soaking } \\
\text { temperature }\end{array}$ & $1050^{\circ} \mathrm{C}$ & $1050^{\circ} \mathrm{C}$ \\
$\begin{array}{l}\text { Type of die } \\
\text { Average die }\end{array}$ & Flat dies & Shaped die \\
temperature & $350^{\circ} \mathrm{C}$ & $350^{\circ} \mathrm{C}$ \\
Die lubrication & Colloidal graphite & Colloidal graphite \\
\hline
\end{tabular}

a furnace set at $600^{\circ} \mathrm{C}$ and cooling it to $200^{\circ} \mathrm{C}$ by switching off the furnace. Effect of solution treatment temperature on the tensile properties and microstructure was studied in the temperature range of $900-1050^{\circ} \mathrm{C}$ to select the optimum cycle for post-heat treatment of the forged dome.

All the samples were conventionally polished and electrolytically etched with $10 \%$ oxalic acid to reveal the grain structure. The microstructure of the alloy was examined with an optical light microscope (make: OLYMPUS GX-71) and scanning electron microscope (make: CARL ZIESS Evo50) equipped with OXFORD makes energy dispersive X-ray spectroscopy (EDS). The conditions used for EDS analysis are EHT voltage, $20 \mathrm{kV}$, and probe current, $600 \mathrm{pA}$. The grain size was determined by a linear intercept method using IMAGEJ image analysis software. Tensile test was conducted on the round subscale specimen ( $25 \mathrm{~mm} \mathrm{GL}$ ) using an INSTRON $5500 \mathrm{R}$ UTM at a nominal strain rate of $0.001 \mathrm{~s}^{-1}$ in both solution treated (ST) and solution treated and aged (STA) condition. Specimens were solution treated at $980^{\circ} \mathrm{C}$ for $0.5 \mathrm{~h}$ followed by air cooling and aged at $720^{\circ} \mathrm{C}$ for $8 \mathrm{~h}$ followed by furnace cooling to $620^{\circ} \mathrm{C}$ and soaking for $8 \mathrm{~h}$ followed by air cooling.

\section{Results and Discussion}

3.1. Forging. The process employed for realization of the hemispherical domes is shown in Figure 1. The first process was designed based on our previous experience with closed die hammer forging of Ti-5Al-2.5Sn alloy [10]. In process1 (P1), the input material of $200 \mathrm{~mm}$ diameter and $40 \mathrm{~mm}$ height (disc) was upset to a height of $23 \mathrm{~mm}$ with a diameter of $263 \mathrm{~mm}$. This preform was forged in shaped die to produce a $15 \mathrm{~mm}$ thick hemispherical dome as shown in Figure 1. The as-forged dome was transferred from the die and cooled in air. Upon visual inspection, the forging showed free surface cracks. These cracks could be removed by machining the surface. Such forgings will not be rejected because of free surface cracks, but often machining is required to achieve good surface finish. Hence, defect-matrix developed by Arentoft and Wanheim [11] for forging was employed to understand the reason for formation of defects and ways to eliminate them. Table 2 gives defect-matrix for the present process with possible reasons for free surface cracks, with defects in the column and causes in the row. However, the defects and the causes given are limited to this method and will be studied. The symbol " $\mathrm{X}$ " in the table indicates the relation between cause and defect. The possible reasons for formation of free surface cracks may be too high friction, fast cooling, low/high temperature, and improper height $(h) /$ diameter $(d)$ ratio. In the present study, friction was reduced by providing sufficient lubrication between die and job by using colloidal graphite. Hence, too high friction is of no concern.

In this work, material to be forged (Inconel 718) and tools to be used (die design and material) are predetermined. 


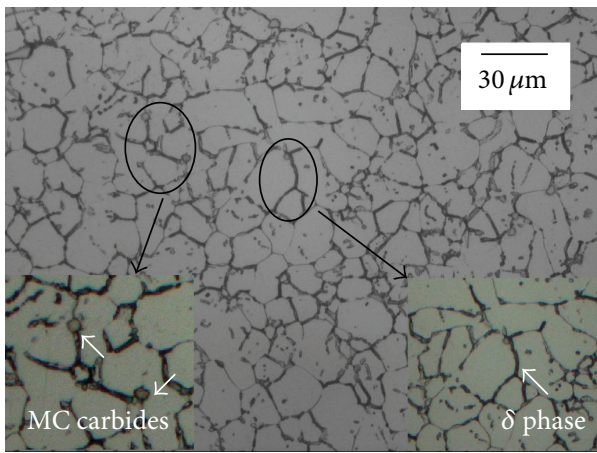

(a)

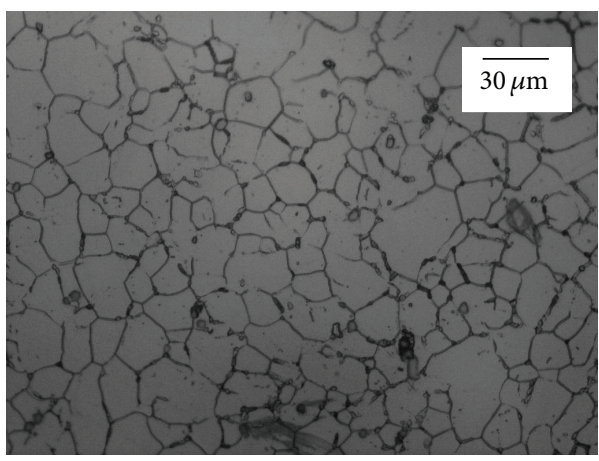

(c)

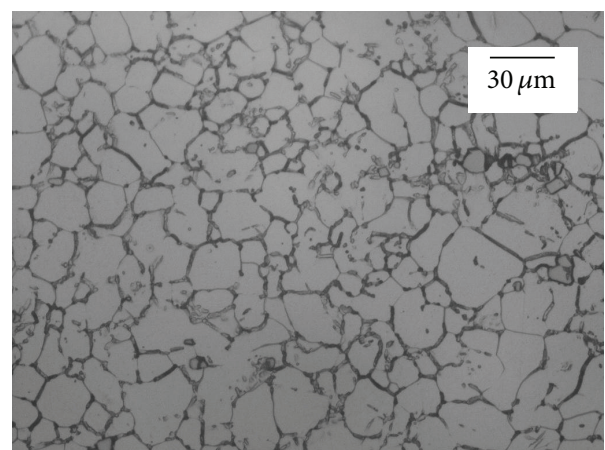

(b)

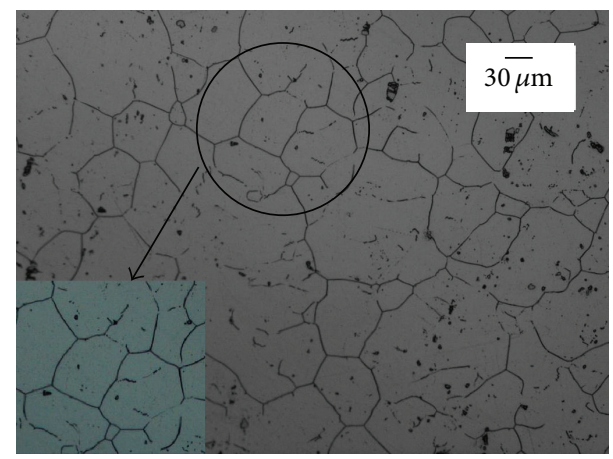

(d)

Figure 2: Effect of temperature on the optical micrographs in solution treated condition: (a) $900^{\circ} \mathrm{C}$, (b) $940^{\circ} \mathrm{C}$, (c) $980^{\circ} \mathrm{C}$, and (d) $1050^{\circ} \mathrm{C}$.

Therefore, efforts were directed towards modification of the preform and process. Under the process, the causes of surface cracks can be fast cooling. The cooling rate has been modified from air cooling as it is in P1 to controlled cooling in process2 (P2). This modification has yielded a crack free forging. It is well established that residual stresses are induced during the hammer forging process and based on the preform shape and size additional localized stresses may be induced. If the stress reaches a threshold level and sufficient time is not provided for relieving the stress, it may result in free surface cracking as observed in P1. By controlled cooling in furnace sufficient time and temperature are provided for stress relieving yielding a crack free dome.

Further in process-3 (P3), the concern of an improper height/diameter $(h / d)$ ratio has been addressed. The process adopted involved direct forging to realise a dome avoiding preforging. A defect-free dome realised through P3 was in agreement with Arentoft and Wanheim [11] that lower $h / d$ ratio was improper selection for the present method. The $h / d$ ratio for disc and preform were 0.2 and 0.08 , respectively. Lower $h / d$ ratio (0.08) will result in severe bending of the job followed by flow of the material along the lower die to form a hemisphere. In the case of $0.2 \mathrm{~h} / \mathrm{d}$ ratio, sufficient height is available for filling the die cavity and enabling the flow of the material without any bending stresses being induced. Preform design and controlled cooling were effectively used in P3 to avoid surface cracking. However, controlled cooling is not economical and industrially feasible. Keeping this in mind, an attempt was made to design process-4 (P4) which can meet above requirements and could be scaled up. This process involved direct forging followed by air cooling. The forged dome was free of surface cracks. All the forged domes were subjected to dye-penetrant test and ultrasonic inspection after solution annealing and proof machining, and no recoverable indications were observed. From the above discussion using defect-matrix, it may be ascertained that improper selection of preform is the primary reason for free surface cracking. Nevertheless, some additional numerical simulation of the process may be necessary in order to verify the output from the defect-matrix.

3.2. Selection of Solution Annealing Temperature. The microstructure of the solution treated sample at $900^{\circ} \mathrm{C}$ consisted of fine equiaxed grains decorated with grain boundary delta phase and MC type primary carbides [12-14]. Delta phase has composition of $\mathrm{Ni}_{3} \mathrm{Nb}$ with orthorhombic crystal structure. It forms above $700^{\circ} \mathrm{C}$ and has solvus around $1000^{\circ}$. It is reported that rate of formation of delta phase is maximum at $900^{\circ} \mathrm{C}[15$, 16]. Azadian et al. [16] reported that delta phase nucleates at the grain boundaries followed by growth of needles extending into the grains. Carbides were observed at the grain boundary and occasionally within the grains as indicated by arrows in Figure 2(a). Further, increase in the solution treatment temperature $\left(940-980^{\circ} \mathrm{C}\right)$ has resulted in the decrease in the volume fraction of the delta phase as shown in Figures 2(b) and 2(c). Complete dissolution of delta phase and grain growth was observed at $1050^{\circ} \mathrm{C}$ as shown in Figure $2(\mathrm{~d})$. Nevertheless, primary carbides were not affected by high 
TABLE 2: Defect-matrix for the forging process [10].

\begin{tabular}{ccccccc}
\hline Defect-matrix & $\begin{array}{c}\text { Tribology } \\
\text { Too high } \\
\text { friction }\end{array}$ & $\begin{array}{c}\text { Wrong } \\
\text { height/diameter } \\
\text { ratio }\end{array}$ & $\begin{array}{c}\text { Too large } \\
\text { volume }\end{array}$ & Bad geometry & Too fast cooling & Fixed \\
\hline Surface cracks & $\mathrm{X}$ & $\mathrm{X}$ & $\mathrm{X}$ & $\mathrm{X}$ & $\mathrm{X}$ & Fixed \\
\hline
\end{tabular}

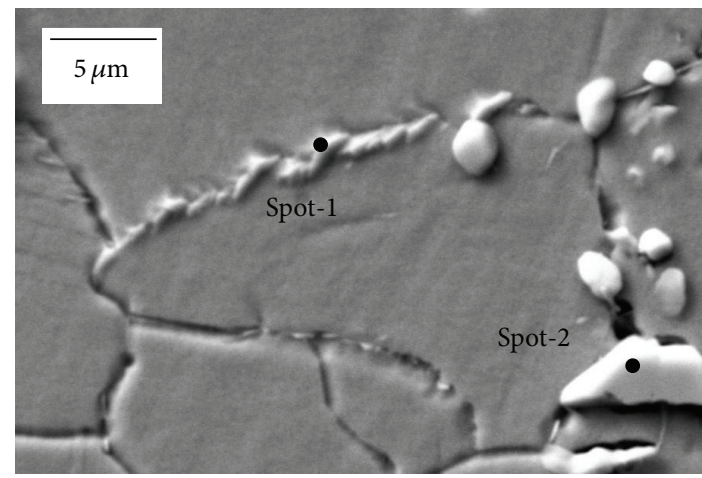

(a)

Spot-1

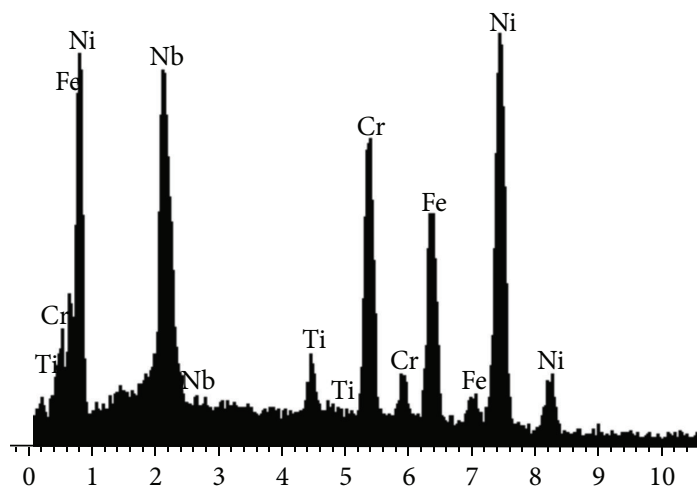

(c)

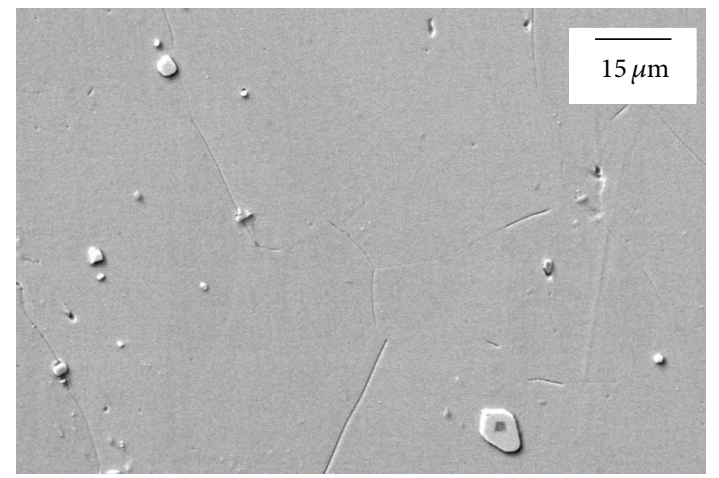

(b)

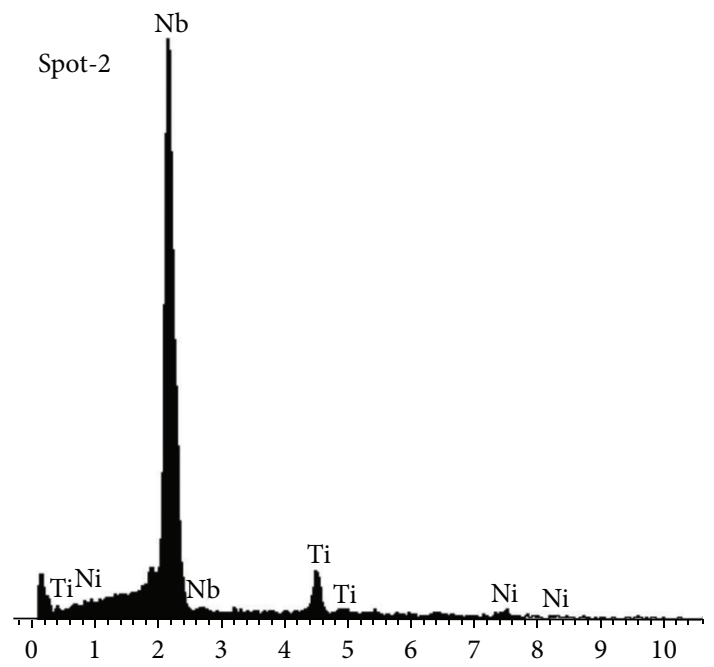

(d)

FIGURE 3: SEM micrographs and corresponding EDS spectra from the solution treated samples. (a) SEM micrograph of ST-900 ${ }^{\circ} \mathrm{C}$ sample, (b) SEM micrograph of ST- $1050^{\circ} \mathrm{C}$ sample, (c) EDS spectrum from spot-1 in (a), and (d) EDS spectrum from spot-2 in (a).

temperature solution treatment $\left(1050^{\circ} \mathrm{C}\right)$. Figure 3 shows the SEM micrographs of the solution treated samples at 900 and $1050^{\circ} \mathrm{C}$. The typical features in $900^{\circ} \mathrm{C}(\mathrm{ST})$ were needle shaped phase along the grain boundary and large carbides at the grain boundaries as shown in Figure $3(\mathrm{a})$. At $1050^{\circ} \mathrm{C}(\mathrm{ST})$, the grain boundaries were free of any phase, but the carbides distribution was unaltered as shown in Figure 3(b). The energy dispersive X-ray spectroscopy (EDS) spectra obtained using quantitative method from the grain boundary phase and carbide are shown in Figures 3(c) and 3(d), respectively. The EDS spectrum in Figure 3(c) shows prominent peaks of $\mathrm{Ni}$ and $\mathrm{Nb}$ along with Fe and $\mathrm{Cr}$. Considering the size of the analysed phase $(\approx 1 \mu \mathrm{m}$ in thickness), the additional peaks of $\mathrm{Fe}$ and $\mathrm{Cr}$ may be due to contribution of the matrix. From the morphology (needle shape) and EDS spectrum of the phase, the possible phase can be $\mathrm{Ni}_{3} \mathrm{Nb}$. The EDS spectrum from the large particle displays prominent peaks of $\mathrm{Nb}$ along with Ti confirming the carbides are rich in $\mathrm{Nb}$ and $\mathrm{Ti}$. It can be presumed from the shape, size, and EDS spectrum that large particles are $(\mathrm{Nb}, \mathrm{Ti}) \mathrm{C}$. The observations made are in agreement with the earlier works on Inconel 718 [14-17].

Tensile properties of the alloy subjected to solution treatment at different temperature and aged as per standard cycle are shown in Figure 4 . The tensile properties in the temperature range of $900-980^{\circ} \mathrm{C}$ were in the range of 1426-1467 MPa (ultimate tensile strength), 1216-1241 MPa (yield strength), and 23.3-23.8\% (elongation). At $1050^{\circ} \mathrm{C}$, the ultimate tensile strength and yield strength decreased 


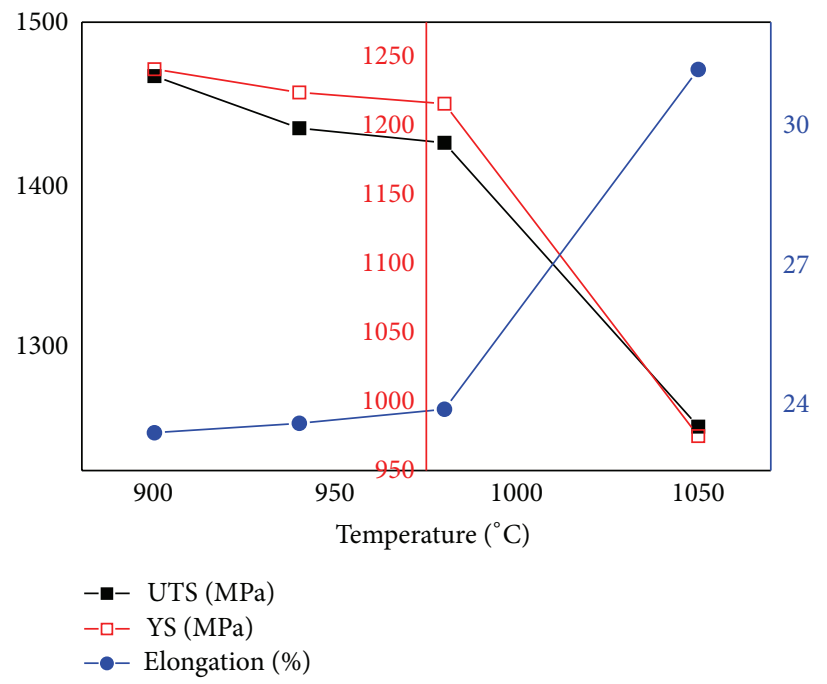

FIGURE 4: Influence of solution treatment temperature on the tensile properties of Inconel 718 after aging.

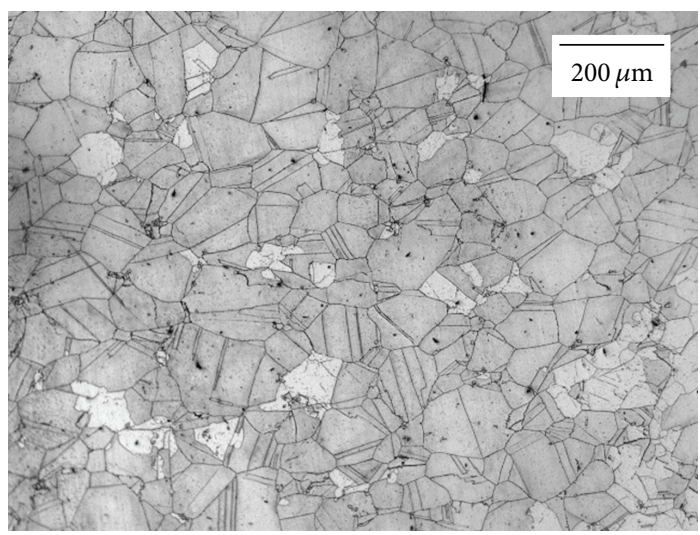

FIGURE 5: Optical micrograph of the Inconel 718 disc used for forging.

to $1252 \mathrm{MPa}$ and $975 \mathrm{MPa}$, respectively, with improvement in ductility $(31 \%)$. The decrease in strength is attributed to dissolution of delta phase and grain coarsening as seen in Figures 2(d) and 3(b). From the optical and SEM micrographs and tensile properties, solution treatment at $980^{\circ} \mathrm{C}$ was selected as appropriate temperature because of combination of strength and lower volume fraction of delta phase. The deleterious effect of delta phase on the high temperature mechanical properties and room temperature ductility is reported in literature [15-19].

\subsection{Microstructure of Solution Annealed Dome. Figure 5} shows the microstructure of the disc ( $\varnothing 200 \mathrm{~mm})$ used in the present study. It has been observed that microstructure had fully recrystallised equiaxed grains with a mean grain size of $88 \pm 10 \mu \mathrm{m}$. Figure 6 shows the microstructure of the dome forging at three locations after solution treatment. At the top of the dome, the microstructure appears to be recrystallised and has relatively larger grains, which have undergone recovery as shown in Figure 6(a). The grain size was measured to be $62 \pm 10 \mu \mathrm{m}$. The extent of recrystallisation mainly depends on total strain, strain rate, and temperature [10]. Therefore, it can be assumed that "necklace" recrystallisation observed at the top of the dome may be attributed to lower deformation and die chilling. However, it was reported that such limited or partial recrystallised structure does not affect the mechanical properties (tensile and fatigue) [3]. The midportion of the dome had slightly elongated grains with the remains of some large recovered grains as shown in Figure 6(b). The elongated grains also indicate that the flow of material was along the wall of the shaped die. This is the portion of the dome, which experiences maximum deformation. Bottom of the dome had fully recrystallised structure with annealing twins, and grain size was $52 \pm 12 \mu \mathrm{m}$ as shown in Figure 6(c). This portion of the dome experiences moderate deformation and low die chilling allowing complete recovery and recrystallisation. The grain size of the dome taken at different locations was found to be finer than ASTM No. 4.

3.4. Mechanical Properties of Solution Treated and Aged Dome. Prior to tensile testing, specimens were solution treated and aged. Properties of the disc and dome forging are given in 

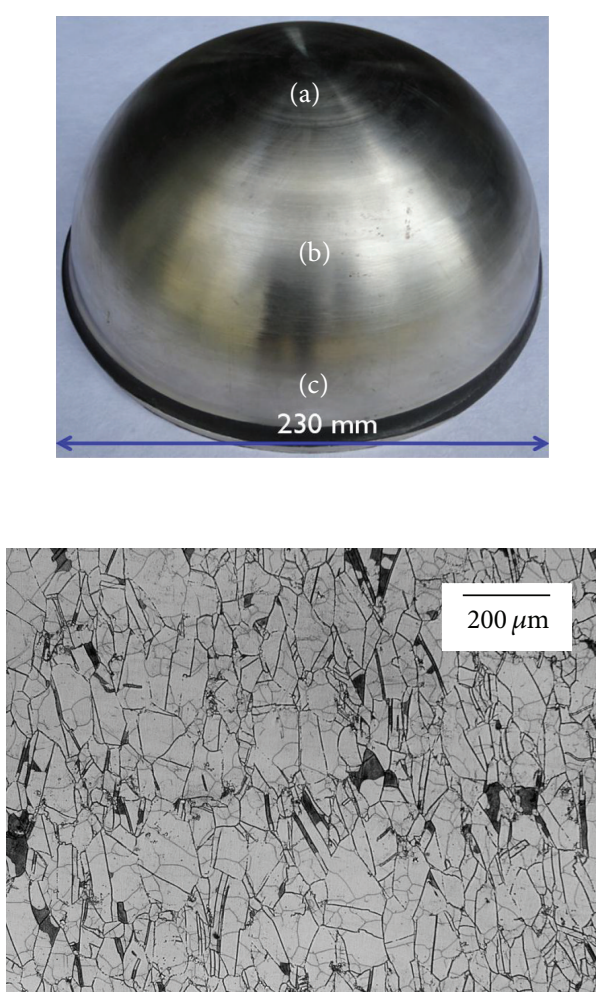

(b)

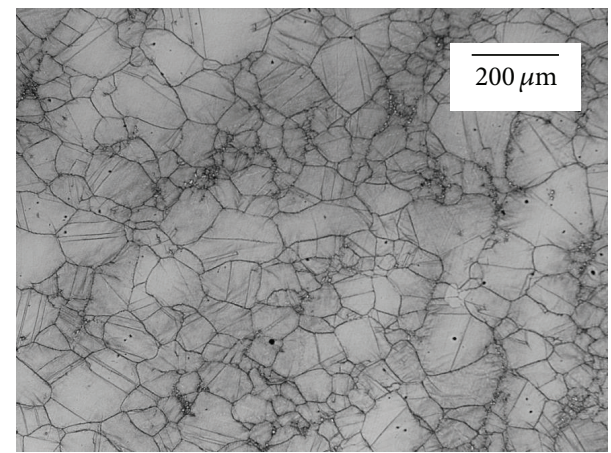

(a)

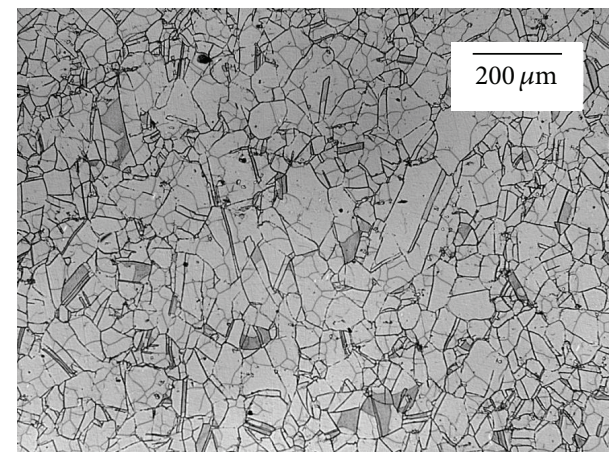

(c)

FIGURE 6: Optical micrographs of Inconel 718 of dome forging after solution treatment: (a) top of the dome, (b) mid-portion of the dome, and (c) bottom of the dome.

TABLE 3: Typical mechanical properties of the disc and forged dome.

\begin{tabular}{|c|c|c|c|c|c|c|}
\hline & $\begin{array}{c}\text { Forging } \\
\text { temperature } \\
\left({ }^{\circ} \mathrm{C}\right)\end{array}$ & $\begin{array}{l}\text { Heat treatment } \\
\text { condition }\end{array}$ & $\begin{array}{l}\text { UTS } \\
\mathrm{MPa}\end{array}$ & $\begin{array}{l}\text { YS } \\
\mathrm{MPa}\end{array}$ & $\begin{array}{c}\% \\
\text { elongation } \\
(25 \mathrm{~mm})\end{array}$ & $\begin{array}{c}\% \\
\text { RA }\end{array}$ \\
\hline \multirow{2}{*}{$\begin{array}{l}200 \mathrm{~mm} \text { diameter disc } \\
\text { (raw material) }\end{array}$} & - & ST & 1104-1115 & $827-850$ & $31-34$ & $30-35$ \\
\hline & - & STA & 1295-1319 & $1134-1160$ & $16-20$ & $27-32$ \\
\hline Dome forgings & 1050 & STA & 1359-1385 & $1208-1216$ & $15-18$ & $25-28$ \\
\hline
\end{tabular}

Table 3. The yield strength (YS) and ultimate tensile strength (UTS) of the disc were $839 \mathrm{MPa}$ and $1111 \mathrm{MPa}$, respectively, in solution treated (ST) condition. They increased to $1154 \mathrm{MPa}$ (YS) and $1312 \mathrm{MPa}$ (UTS) after aging treatment. The dome has shown improved properties compared to the disc because of mechanical working that occurred during forging with an average value of $1210 \mathrm{MPa}$ (YS) and $1362 \mathrm{MPa}$ (UTS). However, better mechanical properties and fine microstructure can be achieved by lowering the forging temperature [8].

\section{Conclusions}

To summarise, closed die hammer forging can be employed for production of $\varnothing 200 \mathrm{~mm}$ hemispherical domes of Inconel 718. Defect-matrix was employed to overcome the free surface cracking observed in the forged dome. Post-solution annealing temperature for the domes was selected as $980^{\circ} \mathrm{C}$, considering good tensile properties, fine grains, and lower content of delta phase. Solution annealed dome showed nonuniform microstructure: partially, recrystallised grains at the top, fully, recrystallised grains with annealing twins at the bottom, and fine elongated grains at the midportion of the dome. Grain size of the hemispherical dome at all locations was finer than ASTM No. 4 and tensile properties of forged dome were better than the feedstock used for forging.

\section{Conflict of Interests}

The authors declare that there is no conflict of interests regarding the publication of this paper.

\section{Acknowledgment}

The authors would like to express sincere gratitude to Director of VSSC for his kind permission to publish this work. 


\section{References}

[1] J. G. Hust and A. F. Clark, "A survey of compatibility of materials with high pressure oxygen service," Cryogenics, vol. 13, no. 6, pp. 325-336, 1973.

[2] W. A. Chandler, R. R. Rice, and R. K. Allgeier, "Apollo experience report-the cryogenic storage system," Tech. Rep. TN D7288, NASA, 1973.

[3] J. F. Uginet and J. J. Jackson, "Alloy 718 forging development for large land-based gas turbines," in Superalloys 718, 625, 706 and Derivatives, pp. 57-67, 2006.

[4] R. C. Schwant, S. V. Thamboo, A. F. Anderson et al., "Large 718 forgings for land based turbines," in Superalloys 718, 625, 706 and Derivatives, pp. 141-152, 1997.

[5] R. C. Schwant, S. V. Thamboo, L. Yang, and M. Morra, "Extending the size of alloy 718 rotating components," in Superalloys 718, 625, 706, and Various Derivatives, pp. 15-24, TMS (The Minerals, Metals \& Materials Society), 2005.

[6] F. Turner and H. S. von Harrach, "Press forging of superalloys," Materials Science and Technology, vol. 2, no. 7, pp. 733-740, 1986.

[7] N. K. Park, I. S. Kim, Y. S. Na, and J. T. Yeom, "Hot forging of a nickel-base superalloy," Journal of Materials Processing Technology, vol. 111, no. 1-3, pp. 98-102, 2001.

[8] Z. J. Luo, H. Tang, F. C. Zeng et al., "An effective technique for producing high performance IN718 forgings using hammers," Journal of Materials Processing Technology, vol. 28, no. 3, pp. 383-390, 1991.

[9] N. A. Wilkinson, "Forging of 718-the importance of TMP," in Proceeding of International Symposium on SuperalloysSuperalloy 718, vol. 625, pp. 119-133, 1989.

[10] S. K. Singh, P. Muneshwar, K. N. Kumar, B. Pant, K. Sreekumar, and P. P. Sinha, "Development and characterization of ti5al2.5sn-eli alloy hemispherical domes for high-pressure cold helium tanks," Materials Science Forum, vol. 710, pp. 113-118, 2012.

[11] M. Arentoft and T. Wanheim, "The basis for a design support system to prevent defects in forging," Journal of Materials Processing Technology, vol. 69, no. 1-3, pp. 227-232, 1997.

[12] C. Slama and M. Abdellaoui, "Structural characterization of the aged Inconel 718," Journal of Alloys and Compounds, vol. 306, no. 1-2, pp. 277-284, 2000.

[13] M. Dehmas, J. Lacaze, A. Niang, and B. Viguier, "TEM study of high-temperature precipitation of delta phase in inconel 718 alloy," Advances in Materials Science and Engineering, vol. 2011, Article ID 940634, 9 pages, 2011.

[14] R. Li, M. Yao, W. Liu, and X. He, "Effects of cold rolling on precipitates in inconel 718 alloy," Journal of Materials Engineering and Performance, vol. 11, no. 5, pp. 504-508, 2002.

[15] Y. Desvallées, M. Bouzidi, F. Bois, and N. Beaude, "Delta phase in Inconel 718: mechanical properties and forging process requirements," Superalloys, vol. 718, no. 706, pp. 281-291, 1994.

[16] S. Azadian, L.-Y. Wei, and R. Warren, "Delta phase precipitation in inconel 718," Materials Characterization, vol. 53, no. 1, pp. 7$16,2004$.

[17] G. D. J. Ram, A. V. Reddy, K. P. Rao, G. M. Reddy, and J. K. S. Sundar, "Microstructure and tensile properties of Inconel 718 pulsed Nd-YAG laser welds," Journal of Materials Processing Technology, vol. 167, no. 1, pp. 73-82, 2005.

[18] C. M. Kuo, Y. T. Yang, H. Y. Bor, C. N. Wei, and C. C. Tai, "Aging effects on the microstructure and creep behavior of inconel 718 superalloy," Materials Science and Engineering A, vol. 510-511, pp. 289-294, 2009.
[19] L. C. M. Valle, L. S. Araújo, S. B. Gabriel, J. Dille, and L. H. De Almeida, "The effect of D phase on the mechanical properties of an inconel 718 superalloy," Journal of Materials Engineering and Performance, vol. 22, no. 5, pp. 1512-1518, 2013. 

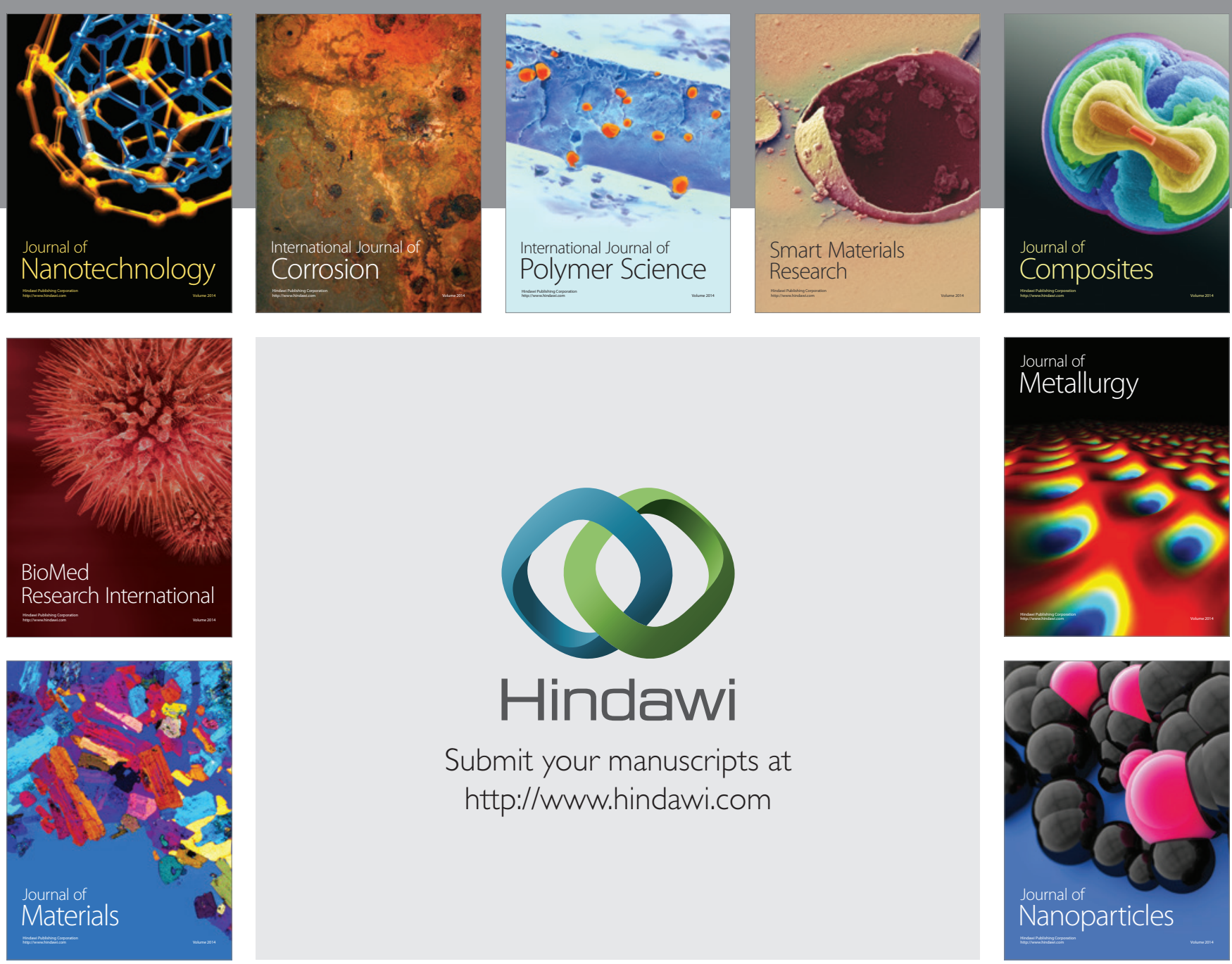

Submit your manuscripts at http://www.hindawi.com
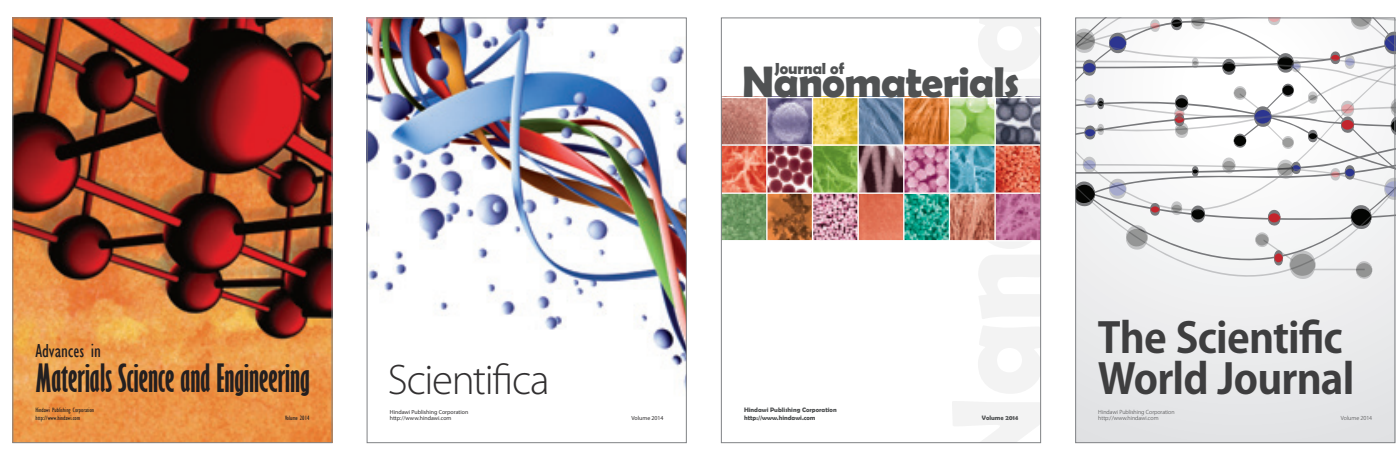

\section{The Scientific World Journal}
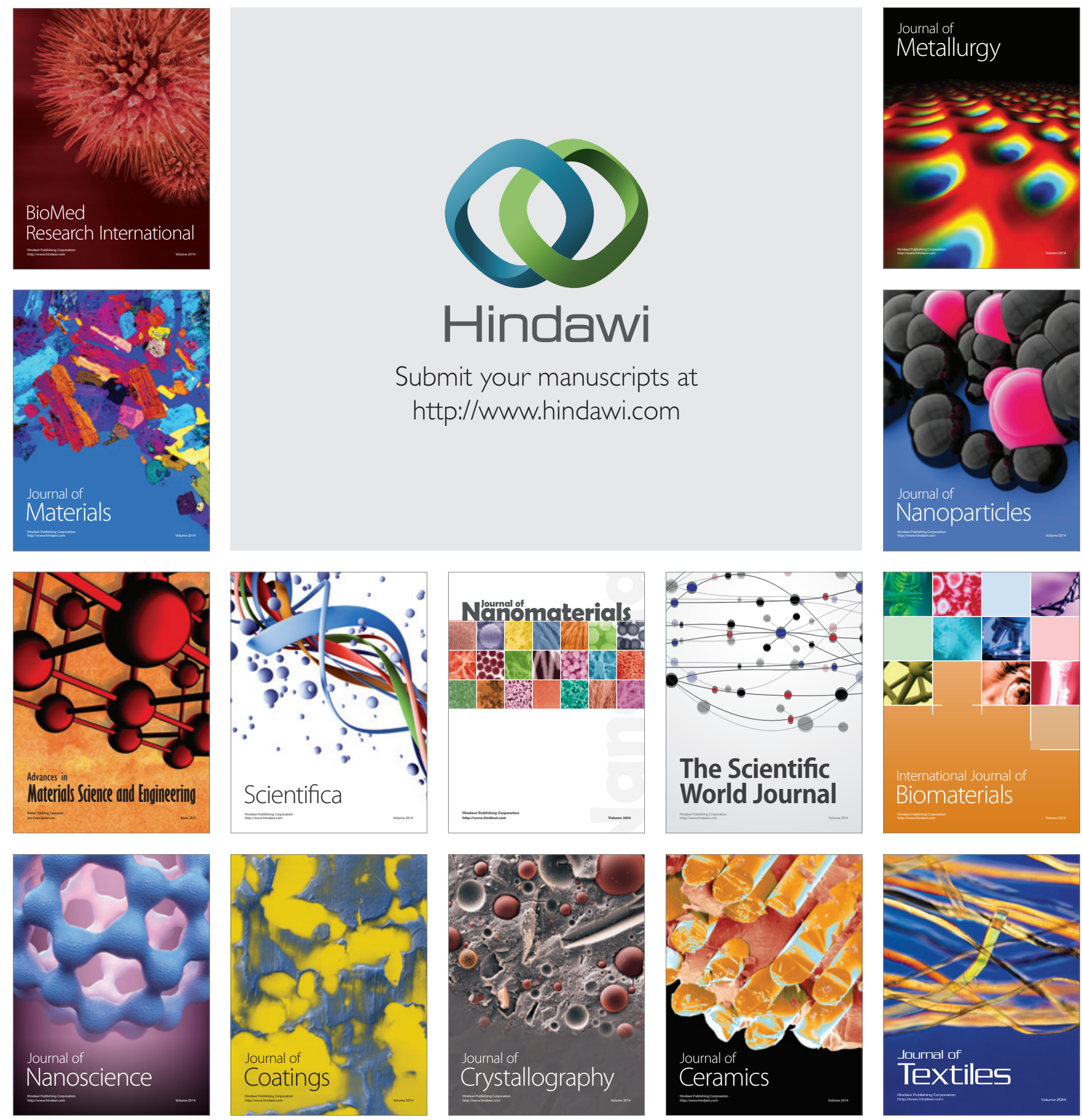